\title{
JNPH
}

Volume 5 No. 1 (Juli 2017)

(C) The Author(s) 2017

\section{EFEKTIFITAS EKSTRAK INFUSA DAUN SALAM (SYZYGIUM POLYANTHUM) SEBAGAI BIOLARVASIDA NYAMUK AEDES SP DI KOTA BENGKULU TAHUN 2016}

\author{
EFFECTIVENESS OF EXTRACT INFUSA BAY LEAF (SYZYGIUM POLYANTHUM) \\ AS BIOLARVASIDA OF AEDES SP MOSQUITO IN BENGKULU CITY 2016
}

\author{
SUSIWATI, KIKI LIA APRIANI, SAHIDAN \\ POLTEKKES KEMENKES BENGKULU
}

\begin{abstract}
ABSTRAK
Latar belakang : Demam berdarah merupakan penyakit yang disebabkan oleh nyamuk Aedes $s p$ sebagai vektor. Pada tahun 2014 sampai dengan tahun 2016, terjadi peningkatan angka kejadian demam berdarah yang cukup tinggi. Dalam memberantas DBD banyak digunakan bahan kimia yang dapat memberikan dampak buruk baik bagi lingkungan, masyarakat dan bahkan dapat menyebabkan vector menjadi resisten. Bahan alami dapat dijadikan alternatif salah satunya yaitu daun salam. Daun salam memiliki kandungan flafonoid, tannin, dan alkaloid yang berfungsi sebagai insectisida.Tujuan : untuk mengetahui efektivitas ekstrak daun salam sebagai biolarvasida nyamuk Aedes sp di kota Bengkulu. Metode: Jenis penelitian ini menggunakan quasy eksperimen dengan menggunakan rancangan post test only with control group design. Sampel yang digunakan adalah larva nyamuk instar III dan IV yang dibagi menjadi 7 perlakuan. 2 perlakuan control negative dan positif, 5 perlakuan diberikan konsentrasi yang berbeda dengan masing-masing larva berjumlah 20 ekor. Hasil: kematian tertinggi terjadi pada konsentrasi $20 \%$ dengan rata-rata kematian sebanyak 16,3 ekor. Kematian terendah terjadi pada konsentrasi 4\% denagn rata-rata kematian 4,3 ekor. Kesimpulan dan saran: Senyawa Tanin dan Flavonoid yang terkandung didalam daun salam yang bersifat toksik terhadap parasit dengan merusak sistem pencernaan dan pernafasan. Perlu dilakukan penelitian lebih lanjut menghilangkan kepekatan warna pada ekstrak daun salam.
\end{abstract}

Kata kunci : daun salam, flavonoid, tannin, larva Aedes sp

\begin{abstract}
Background: Dengue fever is a disease caused by Aedes sp as a vector. From 2014 to 2016, there is a high rate of dengue fever. In combating dengue fever is used chemicals that can adversely affect the environment, society and even can cause vector become resistant. Natural ingredients can be an alternative one of them is bay leaf. The leaves of greetings have the ability of flafonoid, tannin, and alkaloid that serve as insectisida. The purpose: To know the effectiveness of bay leaf extract as biolarvasida Aedes sp mosquitoes in Bengkulu city. Method: This type of study used quasy experiment using post test only with control group design. The samples used were instar larvae of instar III and IV which were divided into 7 treatments. 2 treatment of negative and positive control, 5 treatment given different concentration with each larva amounted to 20 tail. The result: highest mortality occurred at concentration $20 \%$ with mean of death as much as 16,3 tail. The lowest deaths occur with a $4 \%$ concentration with an average $4.3 \mathrm{ec}$ death rate. Conclusions and suggestions: Tanin and Flavonoid compounds
\end{abstract}


contained in bay leaves that are toxic to the parasite by damaging the digestive system and respiratory. It is necessary to do further research to remove the color concentration on the leaf extract of bay.

\section{Keywords: bay leaf, flavonoid, tannin, larva Aedes sp}

\section{PENDAHULUAN}

Penyakit demam berdarah dengue berkembang secara drastis pada beberapa decade terakhir. DBD hampir ditemukan di seluruh daerah belahan dunia yang memiliki iklim tropis dan subtropis, terutama pada daerah perkotaan dan semiurban. Pada tahun 2010 - 2015 beberapa wilayah anggota WHO seperti Amerika, Brazil dan Hawai dilaporkan terjadi peningkatan kasus dari 2,2 juta di tahun 2010 sampai 3,2 juta kasus di tahun 2015 (WHO, 2016).

Indonesia sebagai wilayah yang memiliki iklim tropis menjadi salah satu penyumbang angka kesakitan Demam Berdarah Dengue (DBD). Pada tahun 2014 akhir tercatat 433 kabupaten/kota (sekitar 85,2\%) di seluruh 34 Provinsi melaporkan terjangkit kasus Demam Berdarah Dengue (DBD). Pada tahun 2014 tercatat sebanyak 100.347 kasus dengan angka meninggal dunia sebanyak 907 jiwa. Pada tahun 2015 kasus menurun ke angka 48.480 dengan jumlah orang yang meninggal dunia sebanyak 872 jiwa. Pada akhir Januari 2016 penyakit demam Berdarah Dengue (DBD) terjadi di 9 kabupaten dan 2 kota dari 7 Provinsi di Indonesia. Tercatat angka kesakitan sebanyak 492 orang dengan jumlah kematian 25 orang (Depkes, 2016).

Bengkulu termasuk salah satu daerah penyumbang angka kesakitan DBD yang terus meningkat dari tahun ke tahun. Tercacat pada tahun 2013 terdapat sebanyak 443 kasus Demam Berdarah Dengue (DBD) dan 4 orang meninggal dunia. Incidence Rate DBD di Provinsi Bengkulu Tahun 2013 sebesar 24,2 per 100.000 penduduk. Pada tahun 2014 terjadi peninggkatan angka kesakitan sebanyak 467 kasus dan 13 orang meninggal dunia. Incidence Rate DBD di Provinsi Bengkulu Tahun 201428 per 100.000 penduduk. Terjadi peningkatan yang sangat pesat pada tahun 2015 dengan angka kesakitan tercatat sebanyak 925 kasus dan 19 orang meninggal dunia. Incidence Rate DBD di Provinsi Bengkulu Tahun 2015 sebesar 49,3 per 100.000 penduduk (Dinkes Bengkulu, 2016).

Berbagai upaya pengendalian dilakukan untuk menekan angka kasus yang terjadi. Pengendalian dilakukan secara fisik, biologi maupun dengan cara kimia (Safar, 2009). Pengendalian yang diterapkan pada umumnya dilakukan secara kimiawi, seperti penggunaan abate karena lebih efektif dari cara yang lainnya. Penggunaan bahan kimia dalam waktu yang panjang memberi dampak yang buruk bagi lingkungan serta dapat menyebabkan nyamuk Aedes.sp sebagai vektor penyakit menjadi resisten. Sehingga dilakukan penelitian untuk mencari alternatif bahan yang dapat digunakan sebagai larvasida dan tidak memberi dampak buruk bagi lingkungan dan manusia (Lela dan Eko, 2010).

Tanaman tradisional seperti daun salam (Syzygium polyanthum) dapat menjadi alternative biolarvasida. Daun salam dipilih sebagai alternatif larvasida, karena tanaman ini telah banyak dikenal dikalangan masyarakat selain itu tanaman salam memilki kandungan senyawa yang dapat membunuh insekta (Setyaningsih and Swastika, 2016). Tanaman salam termasuk kedalam family Myrtaceace. Kandungan senyawa kimia daun salam yaitu, minyak atsiri, Flavonoid, dan Tanin. Senyawa tersebut telah diteliti memiliki daya toksik pada berbagai macam insekta salah satunya nyamuk Aedes sp (Wasito, 2011).

Senyawa tannin berfungsi menghalangi serangga dalam mencerna makanan dan juga menyebabkan gangguan penyerapan air pada organisme, sehingga dapat mematikan organisme. Flavonoid dan minyak atsiri 
berperan sebagai senyawa pertahanan yang bersifat toksik yang bekerja sebagai racun terhadap insekta (Fitriana dewi, 2013).

Pada umumnya senyawa kimia didapat dengan menggunakan metode ekstraksi maserasi, namun kelemahan dari metode ini ialah waktu yang lama serta membutuhkan pelarut dalam jumlah yang banyak dan metode ini tidak semua masyarakat dapat melakukannya. Penelitian kali ini di lakukan untuk mengetahui apakah ekstak infusa daun salam (Syzygium polyanthum) dapat memberikan berefek sebagai larvasida, sehingga dapat mengurangi populasi vektor penyebab penyakit Demam Berdarah Dengue (Widiyatmoko, 2013).

Dari penjelasan diatas mendorong peneliti untuk mengadakan penelitian tentang efektivitas ekstrak infusa daun salam dalam membunuh larva Aedes sp dengan metode infusa, untuk mengetahui potensi ekstrak tanaman sebagai pilihan baru sebagai larvasida serta meningkatkan pemanfaatan daun salam sebagai biolarvasida dengan harapan dapat membantu menurunkan angka kejadian DBD di kota Bengkulu.

\section{METODE PENELITIAN}

Jenis penelitian ini adalah quasy eksperimen dengan rancangan penelitian post test onlywith control group design, dimana objek penelitian ini dibagi menjadi dua kelompok perlakuan. Kelompok pertama disebut sebagai kelompok perlakuan, yaitu kelompok yang diberi ekstrak daun salam dengan konsentrasi yang berbeda. Kelompok yang kedua disebut sebagai kelompok kontrol.

Populasi dalam penelitian ini adalah 420 ekor larva nyamuk Aedes sp instar III dan sampel pada penelitian ini adalah 200 gram daun salam .Penelitian ini dilakukan untuk mengetahui kemampuan ekstrak daun salam (Syzygium pholianthum) dalam memalikan larva Aedes sp dengan konsentrasi 4\%, 8\%, $12 \%, 16 \%$ dan $20 \%$ dalam waktu 24 jam. Daun salam sebanyak 200 gram di keringkan pada ruangan lalu di haluskan dan buat larutan ekstrak sesuai dengan konsentrasi yang diinginkan. Kemudian larutan dimasukkan kedalam cup, lalu di masukkan 20 ekor larva nyamuk. Lakukan pengulangan sebanyak 3 kali dan pengamatan dilakukan setelah 24 jam perlakuan. Penentuan konsentrasi ekstrak infusa daun salam:

a) Konsentrasi $4 \%$, yaitu 4 gram daun salam dalam $100 \mathrm{~mL}$ aquades.

b) Konsentrasi $8 \%$, yaitu 8 gram daun salam dalam $100 \mathrm{~mL}$ aquades.

c) Konsentrasi $12 \%$, yaitu 12 gram daun salam dalam $100 \mathrm{~mL}$ aquades.

d) Konsentrasi $16 \%$, yaitu 16 gram daun salam dalam $100 \mathrm{~mL}$ aquades.

e) Konsentrasi $20 \%$, yaitu 20 gram daun salam dalam $100 \mathrm{~mL}$ aquades.

\section{HASIL PENELITIAN}

Pada penelitian ini setelah 24 jam pemaparan, larutan ekstrak daun salam mampu menyebabkan kematian yang bervariasi terhadap larva Aedes sp bahkan sampai konsentrasi tertinggi. Rata-rata kematian meningkat seiring dengan peningkatan pada tiap konsentrasi. Pada konsentrasi 4\% rata-rata jumlah larva nyamuk yang mati sebanyak 4 ekor, konsentrasi $8 \%$ rata-rata berjumlah 6 ekor, konsentrasi 12\% rata-rata berjumlah 10 ekor, pada konsentrasi $16 \%$ jumlah larva yang mati rata-rata berjumlah 12 ekor, dan jumlah larva nyamuk mati yang tertinggi terdapat pada kontrasi $20 \%$ dengan rata-rata jumlah larva yang mati sebanyak 16 ekor.

\section{PEMBAHASAN}

Hasil uji biolarvasida menunjukkan bahwa peningkatan jumlah kematian larva Aedes sp terjadi seiring dengan semakin meningkatnya konsentrasi ekstrak infusa daun salam(Syzygum polyanthum). Pada kelompok kontrol negatif tidak ditemukan kematian larva sedangkan pada kelompok kontrol positif ditemukan kematian larva. Hal ini membuktikan bahwa kematian larva Aedes $s p$ 
pada kelompok perlakuan disebabkan oleh paparan ekstrak infusa daun salam(Syzygium polyanthum).

Kematian larva Aedes sp dalam uji larvasida ini memperlihatkan tanda-tanda bahwa larva tidak bergerak bila disentuh tubuhnya berwarna putih dan kaku. Hasil uji larvasida pada ekstrak infusa daun salam(Syzygium polyanthum) terhadap larva Aedes sp menunjukkan kematian larva konsentrasi yang bervariasi. Ekstrak infusa daun salam(Syzigium polyanthum) mampu mematikan larva Aedes $s p$ dengan konsentrasi yang diujikan).

Penelitian ini serupa dengan penelitian Ni Made (2015) ekstrak ethanol daun salam sebagai larvasida terhadap larva nyamuk Aedes aegypti dengan kematian terkecil terjadi pada konsentrasi $2 \%$ didapat persentase kematian sebesar 3,08\% dan jumlah kematian yang tertinggi terdapat pada konsentrasi $10 \%$ dengan hasil persentase kematian 8,6\%. Penelitian yang serupa juga dilakukan oleh Ilham Syam (2015) tentang efektifitas ekstrak buah pare dalam membunuh jentik nyamuk Aedes aegypti.

Hasil penelitian menunjukkan kematian terendah terdapat pada konsentrasi 5\% persentase kematian sebesar 46\%dan kematian yang tertinggi terjadi pada konsentrasi $15 \%$ didapat persentase kematian sebanyak $89 \%$. Berdasarkan penelitian Nela (2013) tentang efektifitas ekstrak serai wangi dalam membunuh larva Aedes aegypti, didapat kematian tertinggi terjadi padda konsentrasi $2500 \mathrm{ppm}$ dengan persentase kematian berjumlah $83 \%$ dan koonsentrasi terendah terjadi pada konsentrasi $10 \%$ dengan rata-rata kematian sebanyak $26 \%$.

Hal ini terjadi karena dengan meningkatkan konsentrasi berarti semakin banyak kandungan senyawa aktif seperti senyawa flavonoid dan alkaloid dalam ekstrak, sehingga senyawa aktif yang terakumulasi pada larva Aedes sp semakin banyak dan menyebabkan larva yang mati akan lebih banyak. Senyawa bioaktif yang ada pada larutan serbuk daun salam (Syzygium polyanthum), seluruhnya larut dalam pelarut air, misalnya flavonoid, alkaloid (Suirta,Mandk,2011. Senyawa yang terkandung didalam daun salam bersifat toksik terhadap larva, seperti Tanin menghalangi serangga dalam mencerna makanan dan juga menyebabkana gangguan penyerapan air pada organisme sehingga menyebabkan kematian (Edoega and State, 2012). Selain itu kandungan Flavonoid menyebabkan larva mengalami kerusakan sistem pernafasan dan menyebabkan kematian, dan Minyak atsiri yang terkandung di dalam daun salam bersifat toksik dengan cara mendenaturasi protein larva serta menghambat kerja enzim sehingga menyebabkan deintegrasi dari membrane sel. Berdasarkan kejadian tersebut senyawa pada daun salam dapat menghambat perkembangan larva dari instar III menjadi instar IV dan instar IV tidak dapat berkembang ke stadium pupa (Anggraini,et al, 2011).

Pada tabel hasil didapat hasil yang bervariasi dimana jumlah larva yang mati pada setiap pengulangan pada masing-masing konsentrasi tidak selalu sama. Hal ini mungkin dipengaruhi oleh variabel-variabel pengganggu yang tidak diteliti seperti kondisi larva. Selain itu dapat disebabkan oleh faktor seperti perlakuan awal pada sampel yang menyebabkan larva trauma. Larva pada penelitian ini mengguanakna larva instar III dan IV karena pada stadium ini secara fisiologi memiliki ukuran yang paling besar dan sistem pertahanan tubuh larva lebih kuat dari instar I dan II (Agnetha, 2010).

\section{KESIMPULAN}

Berdasarkan hasil penelitian efektifitas ekstrak infusa daun salam (Syzygium polyanthum) sebagai biolarvasida nyamuk Aedes sp di kota Bengkulu dapat disimpulkan sebagai berikut:

Ekstrak infusa daun salam (Syzygium polyanthum) efektif dalam membunuh larva nyamuk Aedes $s p$ dengan jumlah kematian yang menunjukkan bahwa semakin meningkat konsentrasi ekstrak infusa daun salam maka semakin tinggi jumlah kematian 
larva Aedes sp. Kematian tertinggi terjadi pada konsenrasi $20 \%$ dengan rata-rata 16,33 ekor. Jumlah kematian terendah terjadi pada konsentrasi $4 \%$, dengan rata-rata kematian sebanyak 4,3 ekor. Bagi peneliti selanjutnya untuk melakukan penelitian lebih lanjut tentang bagian lain dari daun salam seperti, batang, kulit akar dan buah sebagai larvasida nyamuk Aedes sp.

\section{DAFTAR PUSTAKA}

Alejandro, L, Lopez, P., Torre, Y. C. De, Cirio, A. T., Torres, W. De, Elizabeth, A., Suarez, F. and Aranda, S. (2013) vulgarisL . Komposisi dan aktivitas terhadap Aedes', 2013.

Anggraini, A., Hamidah and Moehammadi, N. (2013) 'Uji Efektivitas Ekstrak Daun Jeruk Purut (Citrus hystrix D.C) dan Daun Jeruk Kalamondin (Citrus mitis Blanco) sebagai Biolarvasida terhadap Kematian Larva Instar III Nyamuk Aedes aegypti', Universitas Airlangga, pp. 110.

Aziz, T., Yuanita and Susanti (2010) 'Ekstraksi Eugenol Dari Daun Salam India', Jurnal Teknik Kimia Nomor 3, 17(3), pp. 17-28.

Cahyadi, A., Wahdaningsih, S., Natalia, D., Studi, P., Dokter, P., Kedokteran, F., Tanjungpura, U., Barat, K., Farmasi, P. S., Kedokteran, F., Pontianak, U. T. and Barat, K. (2015) 'Daya Tolak Infusa Pandan Wangi ( Pandanus amaryllifolius Roxb .) Terhadap Perletakan Telur Nyamuk Aedes SPP', 1(2), pp. 65-71.

Departemen Kesehatan, R. (2016) 'Demam Berdarah Dengue (DBD), Direktorat Jendral Kejadian Luar Biasa Penyakt Menular, Jakarta'.

Dinas Kesehatan, B. (2016) 'Profil Kesehatan Kejadian Demam Berdarah Dengue Bengkulu'.

dr. Widoyono, M. (2011) Penyakit Tropis. kedua. Edited by R. Astikawati. Yogyakarta.

Fitriana dewi, A. (2013) 'Pengaruh Variasi dosis Larutan daun Bandotan
(Ageratumconyzoides L) Trehadap Mortalitas Larva Nyamuk Aedes sp. Sebagai Sumber Belajar Biologi'.

Hartati, S. (2011) Gulma dan Rempah Berkhasiat Obat. pertama. Edited by Elviana dan Putri Komalasari. Bogor.

Holmgren, C. and Wardenaar, E. (2015) 'Uji aktivitas minyak atsiri daun salam ( syzygium polyanthum walp ) terhadap rayap tanah ( coptotermes curvignathus holmgren )', 3, pp. 286-292.

Lela Lailatul, K., Kadarohman, A. and Eko, R. (2010) 'Efektivitas Biolarvasida Ekstrak Etanol Limbah Penyulingan Minyak Akar Wangi (Vetiveria zizanoides) terhadap Larva Nyamuk Aedes aegypti, Culex Sp., dan Anopheles Sundaicus', Jurnal Sains dan Teknologi Kimia, 1(1).

Ni MadePasmiati Setyaningsih, I. K. S. (2015) 'efektivitas ekstrak ethanol daun salam ( syzygium polyanthum ) sebagai larvasida terhadap larva the effectiveness of salam leaf ethanol extract ( syzygium polyanthum ) as larvicide for aedes aegypti larvae', p. 16.

Safar. DAP, Dr. Hj. Rosdiana dan E, Mpd, D. (2010) 'Parasitologo kedokteran, Protozoologi, Helmintologi, Entomologi', in Nurhayati, N. (ed.). Bandung, p. 334.

Satria DS, B. (2013) Koleksi Tumbuhan Indonesia. pertama. Edited by T. A. Prabaswati. Yogyakarta.

Setiawan, Dony HP, S. Kep, Ners., M. M, Hendro Prasetyo, S. Kep, M. K. (2015) Metode penelitian kesehaatan untuk mahasiswa kesehatan.pdf. Pertama. Edited by S. K. Prasetyo, Hendro. Yogyakarta.

Sinaga, S. R. I. R. (2012) 'Uji Banding Efektivitas Perasan Jeruk Purut ( Citrus Hystrix Dc ) Dengan Zinc Pyrithione 1 $\%$ Terhadap Pertumbuhan Pityrosporum Ovale'.

Wasito, H. (2011) Obat Tradisional kekayaan indonesia. pertama. Edited by H. Wasito. Yogyakarta.

Widiatmoko, W. and Pribadi, S. R. W. (2013) 
'Studi Implementasi Lean Six Sigma dengan Pendekatan Value Stream Mapping untuk Mereduksi Idle Time Material pada Gudang Pelat dan Profil', Jurnal Teknik ITS, 2(1), pp. G127-G132.

Widyanto, Falasalado Candra, S. Kep., Nr Cecep Triwibowo, S. Kep., M. S. (2013) Trend Disease 'Trend Penyakit saa Ini. pertama. Edited by A. Maftuhin. DKI Jakarta.

World Health Organization (2016) 'Dengue: guidelines for diagnosis, treatment, prevention, and control', Special Programme for Research and Training in Tropical Diseases, p. x, 147. doi: WHO/HTM/NTD/DEN/2009.1.

World Health Organization, 2016 (2016) 'Dengue dan Deman Berdarah Terparah', pp. 2-6.

Zulkoni, D. H. A. M. S. (2011) parasitologi. pertama. Edited by Abay. Yogyakarta. 